\title{
Gendered Circuits of Care in the Mobility Regime of Alberta's Oil Sands
}

\author{
Sara Dorow* \\ Department of Sociology, University of Alberta \\ Edmonton, Alberta, Canada T6G2H4 \\ sdorow@ualberta.ca
}

\author{
Shingirai Mandizadza \\ Department of Sociology, University of Alberta \\ Edmonton, Alberta, Canada T6G2H4 \\ mandizad@ualberta.ca
}




\title{
Gendered Circuits of Care in the Mobility Regime of Alberta's Oil Sands
}

\begin{abstract}
This article examines the gendered circuits of care found in the fly-in fly-out arrangements of resource extraction zones. In the oil sands of northeast Alberta, Canada, tens of thousands of workers commute long distance between far-flung households and local work camps for rotations of one week or more. Drawing on ethnographic research conducted from the unique vantage point of work camps, we attend to the gendered relations and identities of care that characterize the 'stretched out' arrangements of care between camp and home. We especially address two forms of care: those aimed at helping people cope with camp life, and those aimed at caring for households at a distance. By considering both oil workers and camp staff, we highlight the gendering of the camp/commute regime as a particular geography of social reproduction and foreground the gendered identities - including mobile masculinities - that are reproduced and re-negotiated in the process.
\end{abstract}

Keywords: care; fly-in fly-out; mobility; oil sands; social reproduction; work camps

\section{Introduction}

Feminist geographers engage the new mobilities paradigm to study 'the constellations of power, the creation of identities and the microgeographies of everyday life' (Cresswell 2011, 551) that underpin care work across times and places (Yeoh and Ramdas 2014). Following in this vein, our article links ideas from feminist political economy and mobility studies (see also Roseman, Barber, and Neis 2015) to illuminate gendered circuits of care within a particular mobility regime: the Canadian oil sands industry. From the unique vantage point of oil sands work camps, we find that the spatial and temporal 
re-organization of social reproduction in long-distance commuting involves 'multiple processes of coordination, negotiation and renegotiation with others' (Elliott and Urry $2010,31)$ that reproduce and potentially re-work gendered identities and relations.

One of the world's largest single reserves of fossil fuel, the Athabasca oil sands formation underlies a 140,000 square kilometer region of boreal forest in northeast Alberta, Canada. Like other zones of resource extraction, the oil sands industry has relied on a 'fly-in fly-out' mobility regime, or what is sometimes called long-distance labor commuting (Storey 2016; Pini and Mayes 2012). Tens of thousands of workers fly, drive, or bus back and forth to the oil sands zone on work rotations of one to three weeks (or longer) in length, from home locations that are several hundred to several thousand kilometers away. When they arrive, they are housed and fed in temporary work camps built near to various oil project sites; in 2015, more than one hundred such camps dotted the region (RMWB 2015), some a short drive from a population center and others more remote and reachable only by air strip. These arrangements constitute a 'mobility regime', where a set of principles and norms governing mobility bind unequally positioned workers to each other (Kesselring 2014; Glick Schiller and Salazar 2013; Cresswell, Dorow, and Roseman 2016). Importantly, the system of mobile work in the oil sands includes not just oil workers (construction and other trades workers in operations and maintenance) but also many of the camp workers who feed, house, and clean up after them. While oil sands workers tend to be male, white, and Canadian-born (RMWB 2013; PETROLMI 2015), our research found the camp staff - especially in housekeeping, kitchen and dining services, and janitorial work - to be more often female, racialized non-white, and foreign-born. What these two groups of workers have in common is a 
long-distance commute, access to relatively high wages within their respective fields of employment, and the experience of living and eating in the same encamped space.

We understand care work, both paid and unpaid, to be one component of social reproduction (Bakker 2007, 541) - what Katz $(2001,711)$ refers to as the 'reproduction of the labor force, both generationally and on a daily basis, through the acquisition and distribution of the means of existence, including food, shelter, clothing, and health care'. Social reproduction entails differentiations and inequalities that are geographically and historically specific; since the 1990s, one notable characteristic is the increasing infiltration of capitalist market relations into practices of care (Bakker 2007, 541). In the oil sands, multiple forms of mobile and immobile labor bind places of privatized paid care (the camp) to places of privatized and mostly unpaid care (the household), thus reconfiguring relations of social reproduction across multiple distances and temporal rhythms. One key facet of these relations is the exchange of sociality and care between workers in camp and families and friends elsewhere. As we show below, this circuit of care is integral to the gendering of 'on the move' social reproduction in several ways: mobility arrangements create particular conditions for care; care work is both fixed to, but also flexibilized across, the space-times of home and camp; and subjectivities are negotiated at the intersections of gender and mobility, including in the making of 'mobile masculinities' (Datta et al. 2008; Hopkins and Noble 2009). As a constitutive part of the mobility regime, these gendered circuits of care help to sustain oil production (see also Dorow 2015).

Drawing on interviews and fieldwork conducted in oil sands work camps, our article focuses on the care that 'travels' long distance between camp and home spaces, 
especially among oil workers who return to family homes on a rotational basis. Where the majority of literature on gendered care work in fly-in fly-out contexts focuses on the perspective of the feminized unpaid labor at home that 'anchors' men's mobile work, the vantage point of the work camp as a built-in space of custody and care (Minca 2015) on the other end of the circuit offers a novel intervention. From this locale, where mobile work includes camp staff, we more fully encounter the socio-geographical reconfiguration of paid and unpaid care in the rotational mobility regime as a gendered, as well as a raced and classed, enterprise. We also see how individuals, including men, put in the effort to care within and across 'out of sync' spaces and times (Rolston 2014) and 'fractured' productive and reproductive relations (Roseman, Barber, and Neis 2015). As Gerrard $(2013,312)$ has argued, mobility practices - 'routinized practices whereby people relocate from one site or place to another' - must be placed within their particular structural and cultural contexts so as to understand the challenges women and men must then negotiate. Our concluding comments point to emergent themes in the study of gendered circuits of care as they are reconfigured by the camp/commute mobile regime.

\section{Theorizing gendered circuits of care}

The camp/commute arrangement is a 'regime' in that it has become standard practice in resource extraction and production operations globally, replacing the company town model and being used even in non-remote locations (Storey 2016). This shift is very much on display in the oil sands, where the use of temporary, flexibilized, subcontracted, and mobile workers grew nearly ten-fold between 2000 and 2015 (RMWB 2015). Privatizing the daily camp-based care of the resource worker right into the system of productive employment implicates, in turn, the unpaid domestic work in the homes 
and communities from which workers come and to which they regularly return. Together, these sites comprise a 'stretched out' (Massey [1994] 2005, 2) system of social reproduction that places care work 'within a wider landscape of activities and sites' including non-care employment, family, and various forms of commodification (Kofman 2012, 144). A feminist social reproduction lens foregrounds the wider power-geometries (Massey 2005[1994]) that crisscross this landscape: gender, as well as race and class, mediate who is mobile or immobile, for what kinds of work, and with what effects on spatial and temporal arrangements of emotional and material labors of care (Aure 2013). In work camps, gendered and racialized camp workers are also differentiated from oil workers by lower pay, longer rotational schedules, and less robust travel support. At the same time, these are never neat lines of distinction: camp work includes highly paid chefs and oil work includes non-credentialed day laborers.

A feminist social reproduction perspective ties the gendered, raced, and classed provisioning of care to the reproduction of the labor force (Bakker 2007), and in this case, ties the circulation of care to the reproduction of the mobile labor force and the spatio-temporal re-arrangements it engenders. Indeed, it is the regular back-and-forth of rotational mobile workers between camp and household, which entails constant (albeit not always regular or predictable) spatio-temporal adjustments rather than sustained longterm absence and distance, that especially invites a metaphor of 'circulation'. Attention to 'circuits of affection, care, and financial support' (Hondagneu-Sotelo and Avila 1997, 550 ) is compatible with mobility theory in that it prioritizes the significance of movement and moorings at multiple scales to the organization and experience of social life (Hannam, Sheller, and Urry 2006). In this way, circulation extends the imaginary of care 
beyond a chain of dyadic relations (Yeates 2004), a focus on specific settings (Williams and Crooks 2008), a landscape of fixed places (Milligan and Wiles 2010), or a default to the scale of the transnational (Yeates 2012). A focus on the care that travels between camp and household thus foregrounds 'the reciprocal, multidirectional and asymmetrical exchange of care' (Baldassar and Merla 2013, 43) that occurs within and through a regime of mobile work.

Circuits of care in the oil sands mobility regime reinforce or at least rely on conventional heteronormative roles and discourses, but do so through unconventional temporal and spatial reconfigurations of gendered care roles and relations. These reconfigurations invite 'multiplicity, diversity, fluidity and performativity' (Yeoh and Ramdas 2014, 1205). We consider in particular the making of 'mobile masculinities': the production of masculine subjectivities in and through spatio-temporal movement and migration (Datta et al. 2008; Hopkins and Noble 2009). Prevailing discourses of masculine care - such as through material provision or fathering - are reinforced but also potentially revised within conditions of mobility and immobility (Aure and Munkejord 2015).

The literature on family and care in long-distance rotational commuting has largely been devoted to studying the effects of father absence and nonstandard work shifts on wives and children 'left at home' (Presser 2000; Kaczmarek and Sibbel 2008). A range of effects are explored by these scholars, including: women's 'emotion work' in the service of their mobile mining partners (Pini and Mayes 2012); adjustments in the intensity or resourcing of reproductive labor to accommodate the rotational back-andforth of husbands (Zvonkovic et al. 2005); the significance of regular communication; 
and strain on relationships and workload, including as strain is mitigated by the extra income provided by mobile work (Whalen and Schmidt 2016). There remains a dearth of research within construction and mining work camps (see Jones and Southcott 2015 for one exception), with even fewer examples of multi-sited mobile research between camp and home (see Ferguson 2011 for one exception) that might further open up understandings of the relations between gender, care, and mobility. From the vantage point of camp, our research contextualizes everyday circuits of care - especially as experienced by male oil workers - within the gendered reconfiguration of social reproduction created by a fly-in fly-out mobility regime.

\section{Mobile methods in the time-space of camp}

Our research team conducted fieldwork and semi-structured interviews between July 2014 and March 2016 at five open work camps in the oil sands region. 'Open' camps operate somewhat like a hotel in accepting a range of bookings, while many other camps are 'closed' to company employees only. During our visits, we attempted to tune into the experience and social organization of mobility (Büscher, Urry, and Witchger 2010). We adjusted to camp rhythms to catch people over breakfast or dinner, during work breaks, or in recreation or smoking areas. As a result, the 75 interviews ranged from formal, recorded interviews of more than an hour in length to fifteen-minute conversations written up in fieldnotes. All interviewees gave consent for their information to be used and were assigned pseudonyms. Camp staff and guests (i.e., oil workers) were alerted to our presence via posters in camp common areas and by word of mouth. We also posted notices in gas stations and restaurants along the highway that led to a dozen phone interviews. 
Approximately half of the participants in the study were camp staff housekeepers, kitchen staff, janitors, security personnel, chefs, and a few front desk staff and managers - and the other half were construction, maintenance, and operations workers in the oil industry, often working in a trade. In visits to five different open camps, we only encountered one resident medical staff person; many open camps do not have health or wellness staff. The workers we interviewed commuted from places as close as Edmonton, Alberta (500 kilometers to the south) and as far as St. John's, Newfoundland (6,000 kilometers to the east). The camp staff participants were about half women and half men; more than half of them were foreign-born immigrants. Oil workers were overwhelmingly men (only two women) and were mostly white Canadian, although we had a number of conversations with immigrant oil workers as well. No participants identified as LGBTQ+.

As part of a larger research initiative on employment-related geographical mobility in Canada (Cresswell, Dorow, and Roseman 2016), our interview questions addressed experiences and conditions of commuting, staying in camp, and working, and explored impacts of mobility on identities and relationships at work and at home. Transcripts and fieldnotes were coded by these broad themes (using NVivo) and also by relevant characteristics (type of work, types of mobility, etc.). For this article, we revisited a purposeful sample (Patton 2005) of 25 interviews and fieldnote excerpts containing information-rich narratives about family relations. This helped us develop a more detailed set of thematic codes regarding gendered practices, subjectivities, and circuits of care against the backdrop of the larger study. Such an approach 'extends' 
theory (Burawoy 1991) about gendered social reproduction in the context of mobile work.

\section{Setting the stage: camp as gendered reproductive space}

Long-distance relations of care in the oil sands mobility regime are produced, and thus made comprehensible, within re-arrangements of social reproduction across household and camp. Because extant literature provides more insight into the former than the latter, we offer here a brief ethnographic description of the temporal rhythms and spatial encounters of the work camp. This background sets the stage for our main set of findings (below) on 'traveling' care.

Work camps are made of pre-fabricated rectangular modules articulated to each other in various configurations. The structures and residents of open camps are somewhat less permanent than those of closed camps. Workers stay in small rooms featuring builtin beds, desks, and televisions. Common facilities range from very basic to quite elaborate (four-star chefs, coffee shops, and even movie theaters).

Filled with men who work with heavy equipment and tools at nearby work sites, and who come back to camp hungry and dirty after ten- or twelve-hour day or night shifts, camps are in some ways highly masculinized spaces. But camps also espouse feminized features, starting with the hospitality and 'home away from home' labor provided by the resident camp staff.

When oil workers return to camp after their ten- or twelve-hour shifts out at a nearby oil project, the pattern of activity that ensues is highly choreographed. The entryway (where oil workers take off their dirty boots) usually funnels them into the front reception area, from where hallways lead to the dining hall or to individual rooms. The 
time between work and sleep is short, requiring that workers navigate the spaces of camp in a predictable way each day or night: line up at the dining hall, make the long walk back to your room, briefly unwind before bed. Camp micro-geographies are routinized enough that workers readily rattle them off: 'I finish at 11:00, I logout, and then I would get to my room around 11:15 and at that point I would change into my night clothes for resting. And then I would get my day clothes ready for the next day.'

That everything about camp life is geared toward reproducing oil workers for the next day (or night) of labor shapes the spatial and temporal experience of care work. At any point in time, there is a daily or nightly shift of camp workers providing for the food and housing needs of a corresponding shift of oil workers. As one housekeeper put it, 'the client dictates what happens in camp', 'the client' referring at once to the oil industry and to the oil worker. When oil workers leave for shifts or depart for home, camp staff clean their rooms or fix their TVs; when oil workers re-enter camp through the boot room after a shift, staff mop up after them; when oil workers need to pick up bag lunches on their way out for the next shift, kitchen staff have been up several hours ahead to prepare the bags.

\section{Circuits of care between camp and home}

Exchanging and managing care across distant familial and social networks involves being 'cared about' by distant networks but also 'caring for' (Milligan and Wiles 2010) relationships back home. In this main findings section, we first consider two forms of care that help workers endure camp, then turn to two practices they deploy to manage care back home while away at work. Our focus is on workers who regularly return to family households during their time off. At least half of oil workers have a spouse 
(PETROLMI 2015). While data on the spousal arrangements of camp staff are unavailable, we encountered a high number of married people among the staff - although as discussed below, a dearth of young women with children. Experiences of 'traveling' care vary among workers and are produced in contradictory ways within the same spaces and individuals. We highlight the gendered materialities and discourses of these practices, including as they are articulated with and accommodated by the paid and unpaid social reproductive labors in camp and at home, respectively.

\section{Enduring camp: keeping regular contact}

Both oil workers and camp workers often spoke of camp life as a kind of endurance test. Support from networks back home helped workers deal with the emotional challenges of isolation and distance, making camp life between rotations bearable. Rolanda, a kitchen helper, talked to her grown children every day 'to try to stay sane.' Ricky, a construction worker, used a more colourful description: trying not to go 'shack wacky.'

Maintaining virtual contact with home - wherever home was - included phone and video chats, social media, and quick texts organized around, or sometimes accomplished in spite of, the routinized rhythms and spaces of the camp/commute regime. For some workers, schedules for making contact were followed religiously, same time every day. Kumar, a camp chef, took every opportunity to connect with his wife and baby: 'Anywhere I get time, anywhere I go on a break, I just will go phone her, otherwise we go on Skype...I miss my son for sure. I mean every time, anywhere I get a chance, I tell her to come on Skype so I can see him.' For some, the distance and time difference made for a highly circumscribed schedule of contact. A young construction worker from eastern Canada named Jack, when asked while eating dinner if he would be interested in 
a short interview, glanced at his phone and said this was the only window of time during the day - after his shift in Alberta and right before her bedtime in Newfoundland, three time zones away - when he and his girlfriend were both free to talk for any length of time. Sure enough, two minutes later, Jack's phone rang and he excused himself.

Keeping in touch across time and distance is an individual form of caring labor aimed at creating proximity (Milligan and Wiles 2010). At the same time, the labor performed by camp staff helped to create the time and space for camp dwellers especially oil workers as 'guests' - to keep circuits of contact with distant family and friends. Housekeepers cleaned Jack's room each day, and prep cooks working for Kumar had dinner ready in the dining hall when Jack got off the bus each evening; this regulated regime of gendered, raced, and classed social reproductive care created the conditions for - or perhaps simply conditioned - him to eat and return to his room to connect with his girlfriend across frictions of space and time.

Fly-in fly-out arrangements for staff, in turn, helped set the stage for the regular rhythms of paid care work required by the mobility regime of the oil sands. We found camp staff informally created a sense of familial proximity amongst themselves - at least more so than we found amongst the oil workers. 'We try to laugh and have fun,' said one of the older female housekeepers. 'We do mostly get along with everybody because the people we have around here now, they become your family.' This collective sense was itself a byproduct of a regime geared to fostering reproductive continuity (and thus worker productivity) in the face of high mobility: camp staff tended to be on longer rotations of three weeks; were relatively immobilized in camp, often not leaving its confines during their rotations; often worked alongside and communicated regularly with 
the same co-workers; and were more likely than oil workers to have the option of keeping their camp rooms when away, lending a semblance of continuity to their camp 'home'. These conditions reinforced the creation of informal care relations among camp staff sometimes catalyzed, we observed, by older staff who became informal aunts or uncles that then fed the emotional and material labor needed to provide a 'home away from home' for oil workers.

While the gendering of this mobile regime of reproduction partly rests in hospitality as feminized labor performed by both men and women (Veijola and Jokinen 2008), it also rests in a form of gendered exclusion. Women with young children were sometimes structured out of mobile reproductive work. One human resources manager told us that she actively discouraged them from taking rotational camp jobs because they were 'too distracted' by separation from their children - i.e., too closely tied to family to provide mobile 'family' to others. Camp work was thus the province of older women, single people, and men of all ages, many of them racialized immigrants or temporary foreign workers. These intersecting distinctions, built into mobile employment practices, contributed to making camp a stable base for daily reproducing oil workers for their next shift, including the possibility of regular, if constrained, circuits of connection to home. In those far-flung households, it was most often women who provided long-distance emotional support for mobile men and kept 'the family side ticking along' (Baker and Ciuk 2015, 144).

\section{Enduring camp: counting time and money}

It was not just the regularity of contact but also the possibility of counting time and money with faraway family that helped mobile workers to endure the distance and 
duration of camp life. 'You just push through, you know, [telling yourself] "It's only seven days, it's only seven days,"' said Tim, a trades worker. Given their longer threeweek rotations, a number of camp staff told us they didn't dare start actually counting days until they were at least halfway through it. Time was also marked by counting how much money one was making with each passing day or week.

These practices of counting down the days and counting up the dollars became part of connecting with family across time and space. One male camp cook told us, 'What I do with my wife is, for instance, [each day when we talk] we will count down the days until I'm coming back.' Speaking about how he fought feelings of isolation and despair, a male trades worker noted that he would open his mobile phone and check his bank account to remind himself 'why I am here and what I'm doing,' namely, making good money for his family. Others would dream or talk with family about what they could do with their money when they were home, for example, buying toys for the kids or taking a family vacation.

Once again, these practices link home and camp in gendered circuits of care. First, we are reminded of the 'caring for' emanating from home that helped workers get through each day while they were away. As James, a camp manager, put it, 'the bedrock of continuity' his wife maintained at home enabled him to be absent, and their daily contact helped him count the days until he would return. A second element, one that we might see as a discursive counterpart to women's 'anchoring' care at home, is found in the counting of money. Here, mobile masculine care was imagined and enacted through material provision for family. Indeed, it was especially among participants doing masculinized work (see also Hanlon 2012) - oil workers, construction workers, and then 
also camp chefs and maintenance staff - that we encountered narratives equating each day of rotational absence with larger amounts of material care for family. Emotional endurance of camp was daily converted into 'being a man', doing the right thing, thus tightly entwining affective 'caring about' and material 'caring for' along the circuit of care. This intensified idea of provision-as-care was equally evident in its potential dissolution: Hooper, an ironworker, said he had tried to exit mobile work but the decrease in pay caused more strain on the relationship to his wife than did his long absences (see also Ferguson 2011). In contrast, participants doing feminized work, especially older or married women, seemed less likely to connect to family via a direct monetary calculation, instead narrating their good income as a point of independence, personal satisfaction, or even freedom. The counting of time and money thus differed depending on gendered positions within, and negotiations of, the spatio-temporal distances of the mobility regime.

We also found some workers opting out of connecting with family, reinforcing what Saxinger $(2016,50)$ calls 'conscious acts of separation' among long-distance commuters. Regular connection to family could compound the heartache of distance and isolation, or create the headache of dealing with family matters on top of an already exhausting daily grind (see also Jones and Southcott 2015). Shutting off the circuit, or at least managing the flow, allowed you to 'keep your head down' and concentrate on the work that you came to do. Omar, a camp custodial worker, described how stressful things could be in his home and family life. Drawing his hands up alongside his eyes to mimic blinders, Omar averred that while on rotation 'it's just about work'. The intersectional and gendered elements of these conscious acts of separation require further exploration, 
but it is possible that the conditions of reproduction in the oil sands mobility regime reinforce a mobile masculine subject that can more easily flex in and out of circuits of care than can female mobile workers.

\section{Household care from a distance: fathering and finances}

Thus far we have focused on the gendered forms of labor that contribute to enduring duration and distance. Yet another piece of the puzzle is how workers contribute at a distance to daily social reproduction back home. One way was through long-distance parenting and decision-making communications.

As indicated above, people in camp with young and school-aged children tend to be younger male trades workers who can be away for longer periods because of the childcare provided by people back home - usually by women, whether they are partners, ex-partners, mothers, or mothers-in-law. These workers' contact with home included remote parenting, some of which re-enforced and ensured continuity of masculine subjectivities of father and husband. One notable example came from Garret, a father from Ontario in a joint custody arrangement, who described the series of activities that were unfolding around his teenage daughter's tendency to skip school. A long distance call from the school led to a phone conversation with his daughter that then paved the way for the face-to-face conversation they would have when he returned from his rotation in camp. With a mortgage, a truck, and a daughter and an ex-wife to support, high paying mobile work in the oil sands seemed to Garret like his only option, and this, in turn, brought practical ways of navigating the 'out of sync' relations of camp and home.

We might imagine here a circuit that, by articulating Garret's mobile financial provision to his ex-wife's daily care of their daughter back home, allowed for virtual 
fathering advice and discipline to 'travel' into the management of daily affairs across distance but also into future in-person interactions across rotations. Such spatio-temporal adjustments in masculine caring roles are especially important given their tenuousness: many male mobile workers with families indicated that regular sustained absences from home made them feel they had less of a right to "come [home] and say "we should be doing this, we should be doing that", as one oil worker put it.

Banking and financial decision-making was another form of mobile masculine care for family back home that was re-shaped by the realities of rotational commuting, albeit with different impacts on gendered roles. One long-time oil worker's lament that it fell to him to manage financial decisions even while he was away in camp - 'she's hopeless,' he proclaimed - was also a claiming of economic prowess. But as other researchers (Zvonkovic et al. 2005) have found, this heteronormative imaginary can also be revised by mobile labor. Another long-time oil worker pointed out that his absence was viable because his wife 'took care of everything' while he was gone, where 'everything' crossed conventional divisions of labor to include the management of banking and finances.

As mobile fathering and banking re-spatialized masculine forms of care, they reinforced but also potentially revised gendered divisions of labor. In either case, mobile workers' adjustments to individual caring roles triangulated with the feminized social reproductive labor conducted at both the home and camp 'ends' of the commute, thus calibrating the circulation of care to the fly-in fly-out regime.

\section{Household care from a distance: spatial re-arrangements}

Caring for family was also accomplished through a series of extra-domestic arrangements 
back home that eased or allowed for the distances and temporalities of mobile work. Here, care 'traveled' through in-place proxies and exchanges; often these were informal exchanges amongst men that provided a heteronormative supplement to rotationally female-headed households. One male trades worker, for example, described how a male friend back home helped his wife with yard work during his two-week rotation. He then reciprocated by carrying out maintenance and home repairs for the friend when he physically returned home during his time off. In other cases, the spatial gendered division of labor was challenged; as another oil worker said, '[in my absence] the wife has to step up and be an alpha - she looks after the house, inside and out.'

Sometimes it was the management of spatial mobilities of paid and unpaid caregivers back home -often of kin, and usually of women - that supplemented the absence and accommodated the mobility of oil sands workers. A construction manager named Marco told the story of relocating his young family to the Caribbean to take advantage of the favorable weather and the cheaper cost of paid domestic childcare. Together, he said, these factors were meant to make life easier for his wife during his long absences, and easier for him on his return home. Kumar, the camp chef, had moved his family to the Alberta town where his sister-in-law lived after the birth of his son because, as he said, 'I thought once her delivery happened there should be someone to take care of her. She could live closer to her sister in another town.' His mother's visit from India during and after the birth of their child also solidified the circuit of mobile care necessary to give him 'peace of mind' while away on rotation. The oil sands camp/commute regime can create a domino effect of gendered mobilities of care. 
While such shifts in the socio-geography of care were accomplished via a web of gendered mobilities and immobilities, they were not just the purview of men. For those few women with young or school-age children participating in mobile work in the oil sands, it was often the unpaid care work of kin that made long-distance rotational commuting an option. At one camp, a housekeeper named Martha found it possible to be away for three weeks at a time from her two school-age children thousands of kilometers away in Nova Scotia because her parents, who lived nearby, actually moved into Martha's home with her children during each of her work rotations, then moved back to their own home during Martha's ten days off.

Martha's case illustrates the intersecting forms of inequality found in circuits of care. As beneficiaries of high paying and masculinized mobile work, Marco and Kumar had the choice to physically move their families, keeping heteronormative arrangements intact. The mobile masculine provider was socially reproduced via the gendered sociospatial flexibilization of care across camp and home. Martha's material and affective labor as a camp housekeeper, and her reliance on a familial care chain, are part of this regime; but as a single mother working in less skilled paid labor, Martha's choices for providing 'proxy' care did not include moving her family to a sun destination. Before taking up mobile work in the oil sands, she had looked into moving her family to another part of Atlantic Canada where there were better job options than in her hometown. However, the cost of childcare and of re-locating made this impracticable. Instead, a parallel mobile 'care shift' on the part of her parents allowed Martha to be a longdistance commuter to the oil sands, which in turn allowed her a viable income. The fly-in 
fly-out regime opened a pathway for her to provide for her family, albeit within a circuit of circumscribed choices.

\section{Gendered care in motion: concluding comments}

The stories of Martha and other mobile workers in the oil sands exemplify in two key ways how gender is 'in motion' (Yeoh and Ramdas 2014) within circuits of care: in the differentiated pathways and unequal arrangements that comprise the rotational camp/commute regime, and in the feminized and masculinized subjectivities that are made and negotiated in the process. These are of course interrelated. How gendered 'mobile and multi-local people negotiate emotionally and geographically distant places' (Saxinger 2016,50) is also a matter of the gendered conditions of mobility.

A number of insights from our research invite further inquiry. First, the use of mobile, multi-sited methods could deepen understanding of the gendered geographies that link camp and household as sites of paid and unpaid social reproductive work. Second, where our data have focused attention on heteronormative nuclear family configurations and mobile masculinity, there is more to explore with regard to the implications of single parenthood, divorce, same-sex relationships, extended family, and intergenerational relations in circuits of care among mobile workers. Third, variations in gendered mobile subjectivity - e.g., who can opt in and out of care circuits, and how women narrate their decisions to 'go mobile' - merit further analyses. Finally, where we have only begun to address fly-in fly-out arrangements as raced and classed, more focused study of industry employment practices, mobility logistics, and governing policies could shed light on the mundane institutionalization of power-geometries of mobile work in resource extraction zones. 
To come back to feminist political economy, we find that focusing on the care that travels between home and camp illuminates the interlaid regimes of gender, care, and mobility (adapted from Lutz 2008, 2) that, in turn, reproduce a labor force that is available, flexible, and conditioned for work. Weeks $(2007,238)$ has asserted that 'social reproduction can no longer be usefully identified with a particular site, let alone imagined as a sphere insulated from capital's logics.' This principle is deeply at work in the oil sands, and furthermore, is enacted at the intersections of gender and im/mobility.

\section{Acknowledgements}

Marcella Cassiano gathered many interviews and fieldnotes and conducted initial coding. Chad Doerksen, Jasmine Thomas, and Arpita Mukherjee also contributed to fieldwork. Some interviews are used in cooperation with Dr. Sandrine Jean. This research is part of the On the Move Partnership: Employment-Related Geographical Mobility in the Canadian Context, a project of the SafetyNet Centre for Occupational Health \& Safety Research at Memorial University. On the Move is supported by the Social Sciences and Humanities Research Council through its Partnership Grants funding opportunity (Appl ID 895-2011-1019), the Research \& Development Corporation of Newfoundland and Labrador, the Canada Foundation for Innovation, and numerous university and community partners in Canada and elsewhere.

\section{Notes on contributors}

Sara Dorow is Associate Professor and Chair of Sociology at the University of Alberta. Her research and teaching center on transnationalism, mobility, gender, family, and racialization. For the past decade she has studied these intersections in the context of the oil sands of northeast Alberta, and in the decade previous she studied them in the context of adoption. She is author of the book Transnational Adoption: A Cultural Economy of Race, Gender, and Kinship (NYU press 2006) and co-editor of a special issue of the Canadian Journal of Sociology (2013) on the question of 'community' amidst oil sands development. She is Alberta Team lead for the research project 'On the Move: Employment-Related Geographical Mobility in the Canadian Context.' 
Shingirai Mandizadza is a PhD Candidate in the Department of Sociology at the University of Alberta. She received her MA in Sociology from the University of the Witwatersrand in South Africa. Her research is on gender, land, and relations of power among women in southern Africa in the midst of land reform programs and policies, and is a research assistant to the project ' $O n$ the Move: Employment-Related Geographical Mobility in the Canadian Context.'

\section{References}

Aure, Marit. 2013. “The Emotional Costs of Employment-Related Mobility.” Norsk Geografisk Tidsskrift-Norwegian Journal of Geography 67 (5): 284-294. doi: 10.1080/00291951.2013.847855.

Aure, Marit, and Mai Camilla Munkejord. 2015. "Creating a Man for the Future: A Narrative Analysis of Male In-Migrants and Their Constructions of Masculinities in a Rural Context.” Sociologia Ruralis 56 (4): 531-551. doi: 10.1111/soru.12111.

Baker, Charlotte, and Sylwia Ciuk. 2015. "'Keeping the Family Side Ticking Along.' An Exploratory Study of the Work-Family Interface in the Experiences of Rotational Assignees and Frequent Business Travellers.” Journal of Global Mobility 3 (2): 137-154. doi: 10.1108/JGM-06-2014-0027.

Bakker, Isabella. 2007. "Social Reproduction and the Constitution of a Gendered Political Economy." New Political Economy. 12 (4): 541-556. doi:

10.1080/13563460701661561.

Baldassar, Loretta, and Laura Merla. 2013. "Introduction: Transnational Family Caregiving Through the Lens of Circulation.” In Transnational Families, Migration and the Circulation of Care. Understanding Mobility and Absence in Family Life, edited by Loretta Baldassar and Laura Merla, 3-25. Abingdon: Routledge.

Burawoy, Michael. 1991. "Reconstructing Social Theories." In Ethnography Unbound: Power and Resistance in the Modern Metropolis, by Michael Burawoy, Alice Burton, Ann Arnett Ferguson, Kathryn J. Fox, Joshua Gamson, Leslie Hurst, Nadine G. Julius, Charles Kurzman, Leslie Salzinger, Josepha Schiffman, and Shiori Ui, 8-27. Berkeley: University of California Press. 
Büscher, Monika, John Urry, and Katian Witchger. 2010. “Introduction: Mobile Methods.” In Mobile Methods, edited by Monika Büscher, John Urry and Katian Witchger, 1-19. Abingdon: Routledge.

Cresswell, Tim. 2011. “Mobilities I: Catching Up.” Progress in Human Geography 35 (4): 550-558. doi: 10.1177/0309132510383348.

Cresswell, Tim, Sara Dorow, and Sharon R. Roseman. 2016. "Putting Mobility Theory to Work: Conceptualizing Employment-Related Geographical Mobility.”

Environment and Planning A 48 (9): 1787-1803. doi:

10.1177/0308518X16649184.

Datta, Kavita, Cathy McIlwaine, Joanna Herbert, Yara Evans, Jon May, and Jane Wills. 2008. Mobile Masculinities: Men, Migration and Low Paid Work in London. Working Paper. London: Department of Geography, Queen Mary, University of London.

Dorow, Sara 2015. “Gendering Energy Extraction in Fort McMurray.” In Alberta Oil and the Decline of Democracy in Canada, edited by Meenal Shrivastava and Lorna Stefanick, 275-292. Athabasca: Athabasca University Press.

Elliott, Anthony, and John Urry. 2010. Mobile Lives. London: Routledge.

Ferguson, Nelson. 2011. "From Coal Pits to Tar Sands: Labour Migration between an Atlantic Canadian Region and the Athabasca Oil Sands." Just Labour 17 \& 18: 106-118.

Gerrard, Siri. 2013. "Mobilities, Materialities, and Masculinities: Interconnected Mobility Practices in Norwegian Coastal Fisheries." Norsk Geografisk TidsskriftNorwegian Journal of Geography 67 (5): 312-319. doi:

10.1080/00291951.2013.847482

Glick Schiller, Nina, and Noel B. Salazar. 2013. "Regimes of Mobility Across the Globe.” Journal of Ethnic and Migration Studies 39 (2): 183-200. doi: 10.1080/1369183X.2013.723253

Hannam, Kevin, Mimi Sheller, and John Urry. 2006. "Editorial: Mobilities, Immobilities and Moorings." Mobilities 1 (1): 1-22. doi: 10.1080/17450100500489189. 
Hanlon, Niall. 2012. "Breadwinner Masculinities." Ch. 5 in Masculinities, Care and Equality: Identity and Nurture in Men's Lives, 109-130. London: Palgrave Macmillan.

Hondagneu-Sotelo, Pierrette, and Ernestine Avila. 1997. "I'm Here, but I'm There': The Meanings of Latina Transnational Motherhood." Gender \& Society 11 (5): 548571. doi: 10.1177/089124397011005003.

Hopkins, Peter, and Greg Noble. 2009. "Masculinities in Place: Situated Identities, Relations and Intersectionality." Social \& Cultural Geography 10 (8): 811-819. doi:10.1080/14649360903305817.

Jones, Christopher, and Chris Southcott. 2015. "Mobile Miners: Work, Home, and Hazards in the Yukon's Mining Industry." The Northern Review 41: 111-137.

Kaczmarek, Elizabeth A., and Anne M. Sibbel. 2008. "The Psychosocial Well-being of Children from Australian Military and Fly-in/Fly-out (FIFO) Mining Families." Community, Work \& Family 11 (3): 297-312. doi: 10.1080/13668800801890129.

Katz, Cindi. 2001. "Vagabond Capitalism and the Necessity of Social Reproduction." Antipode 33 (4): 709-728.

Kesselring, Sven. 2014. "Corporate Mobilities Regimes: Mobility, Power and the Sociogeographical Structurations of Mobile Work." Mobilities doi:

10.1080/17450101.2014.887249.

Kofman, Eleonore. 2012. "Rethinking Care through Social Reproduction: Articulating Circuits of Migration." Social Politics: International Studies in Gender, State \& Society 19 (1): 142-162. doi:10.1093/sp/jxr030.

Lutz, Helma. 2008. "Introduction: Migration and Domestic Work in Europe." In Migration and Domestic Work. A European Perspective on a Global Theme, edited by Helma Lutz, 1-12. Aldershot: Ashgate.

Massey, Doreen. 2005 [1994]. Space, Place and Gender. Minneapolis: University of Minnesota Press.

Milligan, Christine, and Janine Wiles. 2010. "Landscapes of Care." Progress in Human Geography 34 (6): 736-754. doi: 10.1177/0309132510364556.

Minca, Claudio 2015. "Geographies of the Camp." Political Geography 49: 74-83.

Patton, Michael Quinn. 2005. Qualitative Research. Hoboken: John Wiley \& Sons, Ltd. 
PETROLMI. 2015. Rotating not Relocatiing: Alberta's Oil and Gas Rotational

Workforce. Report by Petroleum Labour Market Information Division of Enform. http://www.careersinoilandgas.com/media/243739/ rotational-workforce-reportweb-.pdf.

Pini, Barbara, and Robyn Mayes. 2012. "Gender, Emotions and Fly-in Fly-out Work." Australian Journal of Social Issues 47 (1): 71-86.

Presser, Harriet B. 2000. "Nonstandard Work Schedules and Marital Instability." Journal of Marriage and Family 62 (1): 93-110. doi: 10.1111/j.1741-3737.2000.00093.x.

Regional Municipality of Wood Buffalo (RMWB). 2015. The Municipal Census 2015 Report. www.rmwb.ca/census.

Regional Municipality of Wood Buffalo (RMWB). 2013. Municipal Census 2012 Section Five: Project Accommodations Population Count. https://www.rmwb.ca/Assets/Corporate/Census+Reports/CEnsus+report+Part+2+ $-+1 . p d f$.

Rolston, Jessica Smith. 2014. Mining Coal and Undermining Gender: Rhythms of Work and Family in the American West. New Brunswick: Rutgers University Press.

Roseman, Sharon R., Pauline Gardine Barber, and Barbara Neis. 2015. "Towards a Feminist Political Economy Framework for Analyzing Employment-Related Geographical Mobility." Studies in Political Economy 95 (1): 175-203. doi: 10.1080/19187033.2015.11674951.

Saxinger, Gertrude. 2016. "Lured by Oil and Gas: Labor Mobility, Multi-locality and Negotiating Normality \& Extreme in the Russian Far North." The Extractive Industries and Society 3 (1): 50-59. doi: 10.1016/j.exis.2015.12.002.

Storey, Keith 2016. "The Evolution of Commute Work in the Resource Sectors in Canada and Australia." The Extractive Industries and Society 3 (3): 584-593. doi: 10.1016/j.exis.2016.02.009.

Veijola, Soile and Eeva Jokinen. 2008. "Towards a Hostessing Society? Mobile Arrangements of Gender and Labour." NORA-Nordic Journal of Feminist and Gender Research 16 (3): 166-181. doi: 10.1080/08038740802279901.

Weeks, Kathi 2007. "Life within and against Work: Affective Labor, Feminist Critique, and Post-Fordist Politics." Ephemera 7 (1): 233-249. 
Whalen, Heather and Glen Schmidt. 2016. "The Women Who Remain Behind: Challenges in the LDC Lifestyle." Rural Society 25 (1): 1-14. doi: 10.1080/10371656.2016.1152037.

Williams, Alison, and Valorie A. Crooks. 2008. "Introduction: Space, Place and the Geographies of Women's Caregiving Work." Gender, Place \& Culture 15 (3): 243-247. doi: 10.1080/09663690801996254.

Yeates, Nicola. 2012. "Global Care Chains: A State-of-the-Art Review and Future Directions in Care Transnationalization Research.” Global Networks 12 (2): 135 154.

Yeates, Nicola. 2004. “Global Care Chains.” International Feminist Journal of Politics 6 (3): 369-391.

Yeoh, Brenda S.A. and Kamalina Ramdas. 2014. "Gender, Migration, Mobility and Transnationalism.” Gender, Place \& Culture 21 (10): 1197-1213. doi: 10.1080/0966369X.2014.969686.

Zvonkovic, Anisa M., Catherine Richards Solomon, Áine M. Humble, and Margaret Manoogian. 2005. "Family Work and Relationships: Lessons from Families of Men whose Jobs Require Travel.” Family Relations 54(3): 411-422. 